This is a PDF of the accepted version of

Minnegal, M. and P. D. Dwyer (20xx) On Reading Patrol Reports - 2: Travels in East Awin. Journal of Pacific History.

Available on-line at: https://doi.org/10.1080/00223344.2019.1679617

\title{
On Reading Patrol Reports - 2: Travels in East Awin
}

\author{
Monica Minnegal and Peter D. Dwyer \\ University of Melbourne
}

\begin{abstract}
Reports of patrols through remote areas of Papua and New Guinea led by officers of the Australian administration must be read with care. We discuss the case of a patrol report from the mid-1960s where the patrol cannot have travelled the route indicated on the accompanying map. By cross-referencing to reports from later patrols, we provide both an improved reading of the report in question and, more generally, an appreciation of motivations that influenced the knowledge patrol officers produced.
\end{abstract}

Key words: Papua New Guinea, patrol reports, mapping, knowledge production

\section{INTRODUCTION}

Through the years that Australia held administrative oversight in Papua New Guinea, patrols led by officers of the administration (kiaps) were regularly dispatched to document and manage communities often far from government stations. In early 2016, the University of California San Diego Library, with permission from the Papua New Guinea (PNG) National Archives, provided free access to available patrol reports through the library's Digital Collections website (http://lib.ucsd.edu/png-patrol-reports). The collection includes nearly 3000 items from the period 1912 to 1976, with most from the post-World War II era. Though there are many gaps in the record, available reports constitute a major source of information on Papua New Guinea's colonial-era history. In particular, they have much to contribute to understandings of the work entailed in rendering both land and people legible to the colonial state.

Our particular interest is with early contacts in regions of very low population density. In a previous contribution we noted that records of places and people appearing in patrol reports were, for understandable reasons, prone to error and, by way of example, demonstrated ways in which topographic maps, though produced well after particular patrols were undertaken, could be used to refine and correct interpretations provided in those reports. ${ }^{1}$ In the present contribution we examine a patrol report from the mid-1960s in which the route as mapped, while appearing unambiguous, was not the route actually traversed. Here we show how cross-referencing to other reports - a form of triangulation - may be used

Acknowledgements: We thank those who established and made available the University of California at San Diego archive of PNG patrol reports and Laurence Goldman for stimulating discussion. Our own recent research in PNG was supported by Australian Research Council Grant DP120102162.

${ }^{1}$ Peter D. Dwyer and Monica Minnegal, 'On Reading Patrol Reports. 1: South of the Blucher Range', Journal of Pacific History 55 (forthcoming). 
to arrive at both an improved reading of the report in question and, more generally, an appreciation of factors that shaped the knowledge patrol officers produced.

\section{BRIAR'S PATROL}

From 11 January to 7 February 1966, Mike Briar led a patrol from Kiunga to East Awin. ${ }^{2}$ Figure 1 shows Briar's interpretation of the route his party followed.

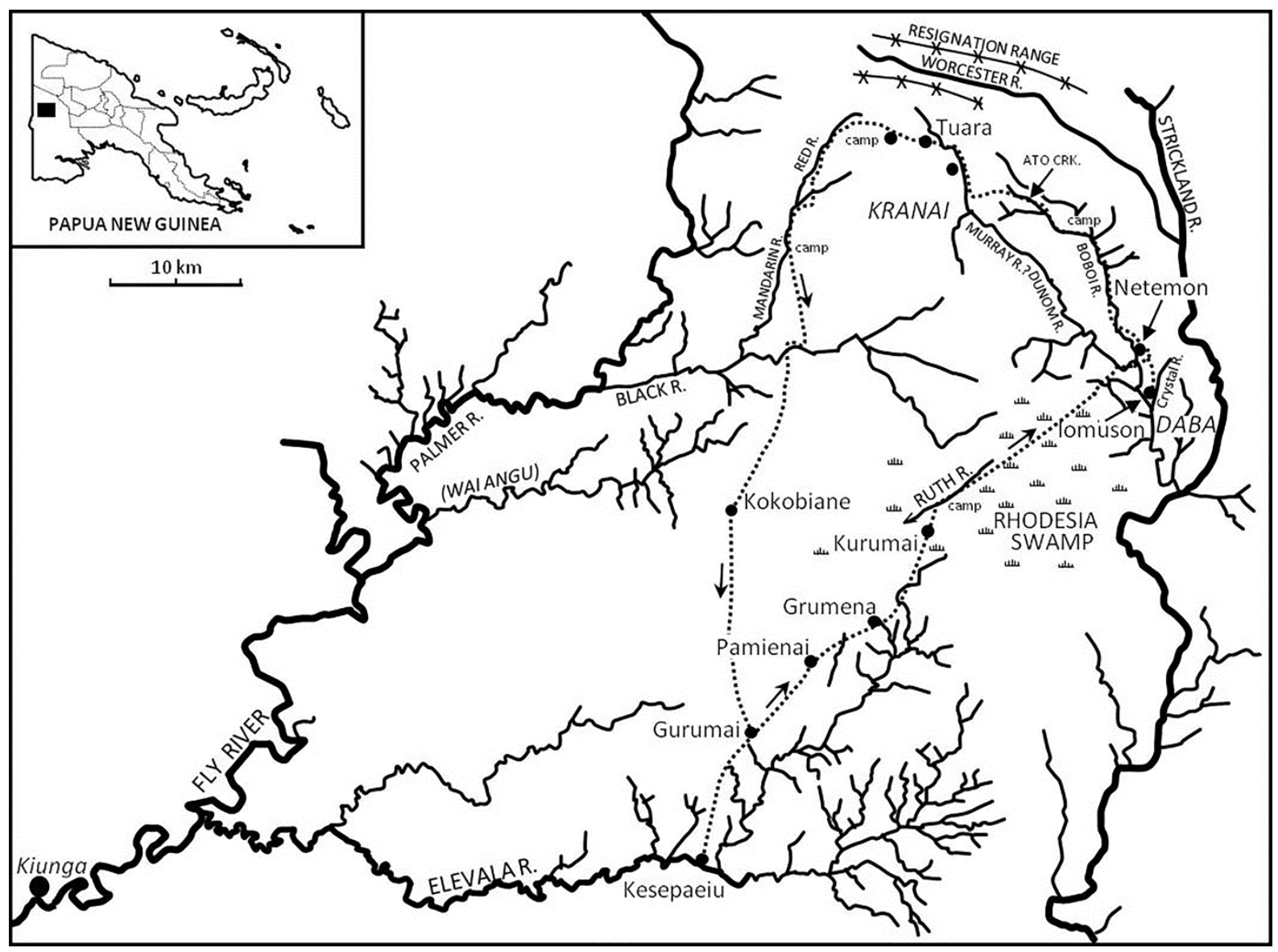

Figure 1. Briar's map, redrawn, showing his interpretation of the route followed by his 1966 patrol from Kiunga to East Awin. We have extended the map to the southwest to include Kiunga and have added Ato Creek, Wai Angu and a scale. Language names are capitalized and in italics. Spelling of place names follows Briar.

From Kiunga, Briar travelled by motorized canoe to the junction of the Fly and Elevala rivers, turned east to Kesepaeiu and joined an advance party of police and 20 carriers. On 13 January he walked to Gurumai. On the 15th his party headed northeast to Pamienai, where accompanying police and the medical assistant turned back to Kiunga. On the 17th Briar, an Awin interpreter and carriers reached Grumena. They spent six days there, conducting a census, repairing the police barracks and rest house, making sago and 'road cutting' to the east-north-east.

\footnotetext{
${ }^{2}$ Mike Briar, Kiunga Patrol no. 5 of 65/66, 11 Jan.-7 Feb. 1966, National Archives and Public Records Services of Papua New Guinea, Patrol Reports, Western District, Kiunga Station, 1965-66, vol. 14, https://library.ucsd.edu/dc/object/bb03091461.
} 
On 23 January the patrol left Grumena, travelling through country not visited by previous government patrols, and camped near a river that Briar named 'Ruth'. On the 24th they travelled northeast through swamp. Progress was slow with the 'patrol ankle to knee deep in mud the consistency of cattle dung at all times'. They left the swamp, crossed and recrossed ‘Dunom River', arrived at ‘Boboi River’ and camped.

On the 25th they encountered 19 people of 'Kranai [Konai] language group' at 'Netemon' and, the following day, walking to the southeast with guides, met people of the 'Daba' language group at 'Iomuson' on the 'Crystal River' ${ }^{3}$ From 'Iomuson', Briar returned to 'Netemon', followed 'Boboi River' north, turned west to 'Dunom River' and then north until, on the 28th, crossing that river near a community named as 'Tuara', he again met 'Kranai' people.

Briar thought that 'Dunom River' might be the Murray, a major tributary of the Strickland River, and that is where he placed the name on his map. From 'Tuara' he depicted his route as east to west across the rugged slopes of what would be the Blucher Range, then steeply south along 'a running cascade that drops in bulging steps for hundreds of feet'. He continued south, following water courses he named as 'Red River' and 'Mandarin River' to reach low-lying country, crossed the 'Black River', spent two nights at Kokobiane and arrived back at Gurumai on 4 February.

In general, the map Briar provided of his patrol corresponds well to his recorded diary entries. There are, however, several difficulties. Briar implied, for example, that he reached 'Dunom River' very soon after he left the swamp country. But if 'Dunom' was the Murray River, as Briar thought and showed on his map, the distance from swamp country would have exceeded $15 \mathrm{~km}$ and entailed a $150 \mathrm{~m}$ increase in altitude. Diary records suggest this was achieved in about two hours. That was an impossible accomplishment. Again, if Briar 'crossed and recrossed' the Murray River at the places shown then either cane bridges or canoes would have been essential, but he makes no mention of these. And though he reported lengthy periods when his party waded in the 'Dunom' this would not have been possible if he was actually on the Murray River at the latitude shown on his map. Finally, at the northern reaches of his travels Briar depicts his route as tracking the presumed Murray River northward for $4-5 \mathrm{~km}$ before crossing to Tuara. If he had, indeed, been on that river, this would have placed him alongside a gorge that Karius had described as having 'walls fully 1,500 feet high'. ${ }^{4}$ Clearly, Briar was not on the Murray River.

\footnotetext{
${ }^{3}$ The name 'Daba' was used in early patrol reports to refer to both Kubo and Febi people who lived near the Strickland River, north of the Damami River. It appears to derive from 'Dabamisi', the name of a 'clan' of Kubospeakers. Monica Minnegal and Peter D. Dwyer, Navigating the Future: An Ethnography of Change in Papua New Guinea (Canberra: ANU Press, 2017), 58.

${ }^{4}$ Charles Karius, 'Appendix A: Report of North-West Patrol', in Territory of Papua: Annual Report for the Year 1926-27 (Canberra: Government Printer, 1928), 98.
} 


\section{THE PATROLS OF PATERSON AND MCGREGOR}

Two patrols conducted more than three years later allow reinterpretation of Briar's route. These were led by William Paterson and John McGregor. ${ }^{5}$

In May 1969, Paterson travelled northwest from Nomad with the aim of contacting communities of 'Kubor' and 'Kone' (Konai) people that had not yet been visited by government. On 15 May the party crossed the Strickland and spent two nights with a community named as 'Sigiafauhamuson' (Figure 2). ${ }^{6}$ On 17 May they followed Sigia River, which Paterson initially mistook for the Murray River, passed a tributary named as 'Koto', and turned west to reach 'Womuson'. ${ }^{7}$ The next day, turning south, they reached a recently abandoned house at 'Netimomuson' that was said to be the residence of about 15 'Kone' people. This house was close to a river known as both Dua and Dunam. Through the next few days, Paterson's party backtracked to Womuson, followed Sigia north, swung east to join Moiyo and followed this down to the Strickland.

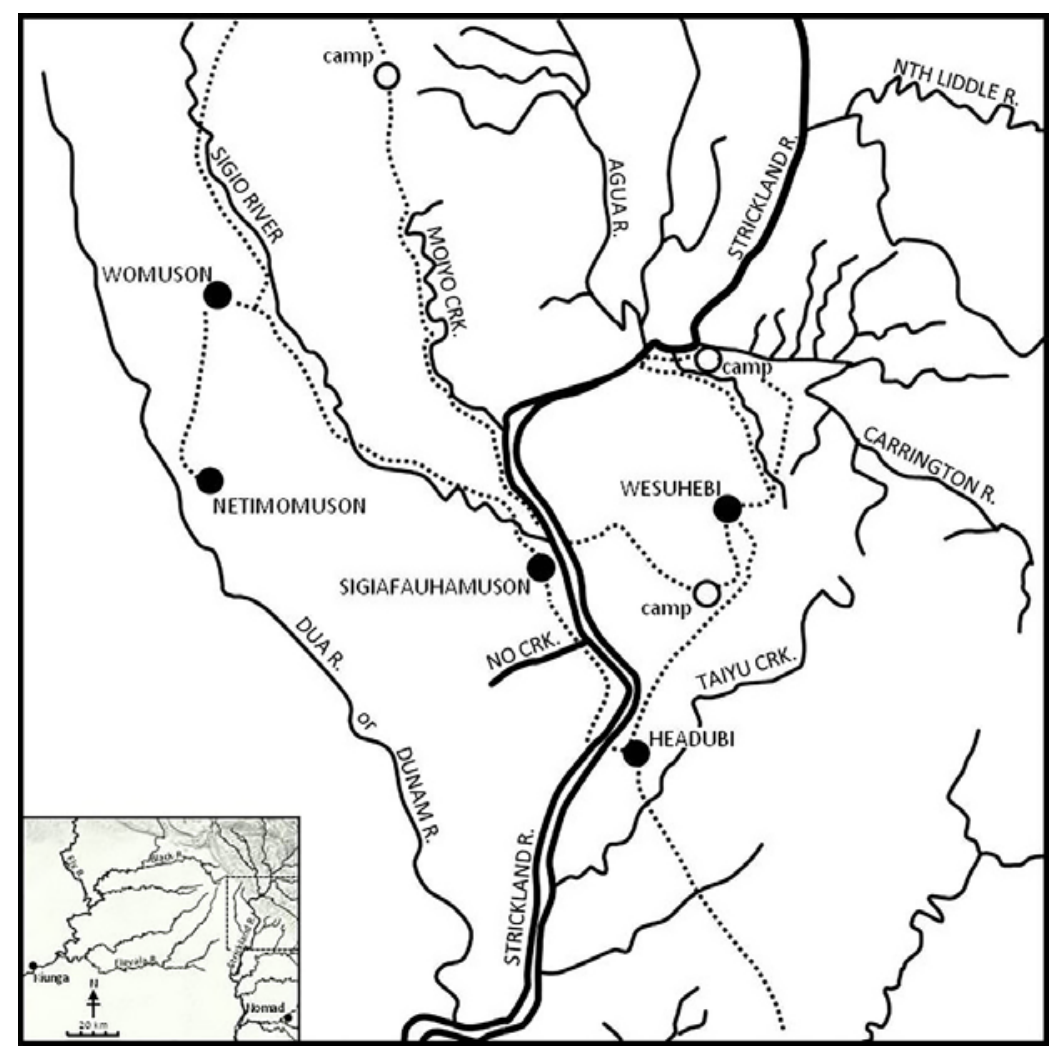

Figure 2. Part of Paterson's map, redrawn, with original spelling, showing his interpretation of the route followed by his 1969 patrol from Nomad to communities west of the Strickland River. Agua is a local name for the Murray River. The inset map has been added.

\footnotetext{
5 John K. McGregor, Kiunga Patrol no. 10 of 1968/69, 15-2 June 1969, National Archives and Public Records Services of Papua New Guinea, Patrol Reports, Western District, Kiunga Station, 1965-66, vol. 17A, https://library.ucsd.edu/dc/object/bb5599296j; William R. Paterson, Nomad Patrol no. 19 of 1968/69, 12-29 May 1969, National Archives and Public Records Services of Papua New Guinea, Patrol Reports, Western District, Nomad Station, 1968-69, vol. 6, https://library.ucsd.edu/dc/object/bb6964499g.

${ }^{6}$ The authors were shown the abandoned site of this longhouse in 1987. The name is from the Kubo language, translating as 'the house (muson) near the mouth (hau) of the stream named 'short Sigia' (Sigia foi)'.

${ }^{7}$ This name, too, is Kubo, translating as 'sago (wo) house (muson)', a term used for a small house built near a grove of sago palms, as a base for extracting flour from those palms.
} 
McGregor's patrol commenced from Kiunga on 15 May 1969, travelling north on the Fly River, entering the Palmer River and turning east into Surprise Creek (Wai Angu) before abandoning the motorized canoe and travelling northeast to reach the Black River on 21st (Figure 3). The primary aim of the patrol was to 'investigate reports of people known as BA and KANAI'.

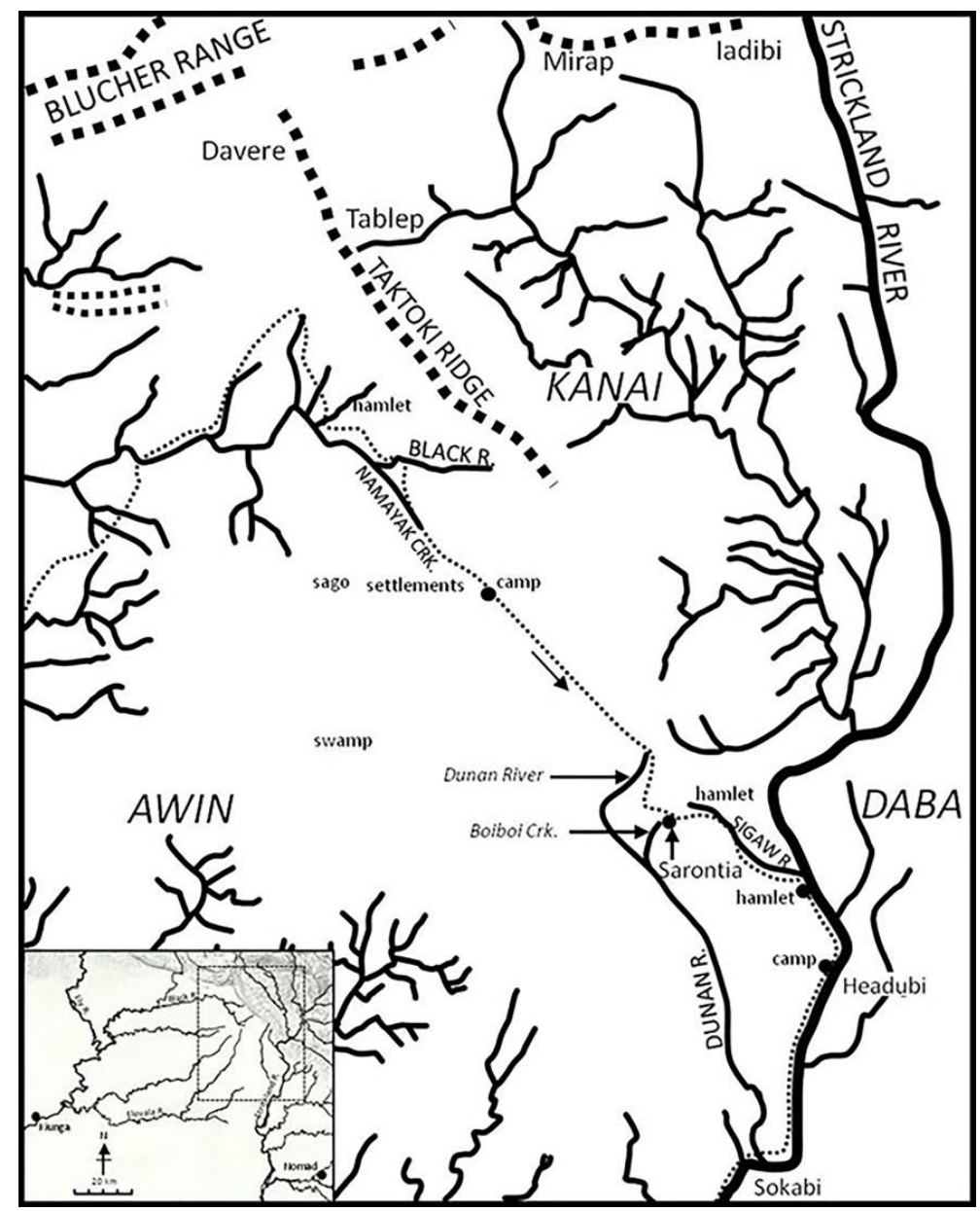

Figure 3. Part of McGregor's map, redrawn, showing his interpretation of the route followed by his 1969 patrol from Kiunga via Black River to communities close to the Strickland River. Language names are capitalized and in italics. The inset map and italicized names have been added.

On 24 and 25 May, McGregor's party travelled to the southeast, often in swamp 'monotonous walking and slow progress' - to cross 'the headwaters of the DUNAN River and then over BOIBOI Creek which flows into the DUNAN'. They slept at 'SARONTIA Hamlet near NITIMO Creek' where local people self-identified as 'KANAI'. On 26 May, the party travelled southeast to 'SIGAW Creek' and followed this to reach the hamlet Paterson had named as 'Sigiafauhamuson'.

On 27 May, McGregor's party camped on the west bank of the Strickland River from where, in the early evening, he visited Paterson who had made camp on the east side of the river, near 'Headubi' (a clan name that was recorded as a place name).

Though the spelling of names varies there can be little doubt that Paterson's 'Dunam River' and McGregor's 'Dunan River' and 'Boiboi Creek' correspond to Briar's 'Dunom' 
and 'Boboi' rivers. 'Netemon' (Briar), 'Netimomuson' (Paterson) and 'Nitimo' (McGregor) will also have the same referent, with Paterson's record simply denoting the 'house' (muson) on the stream named Netimo and with Briar, but not McGregor, detecting and recording nasalization with an ' $n$ '. These two patrol reports show that when Briar thought he had reached the Murray River he was about $12 \mathrm{~km}$ to the south on the watershed of the Dua River. He was in low-lying country where streams drained from foothills into swamps and not in an area where steep foothills were giving way to mountains and where rivers cut through deep gorges.

\section{DISCUSSION}

In the 1960s and 1970s it was common practice for patrol officers to reference the base map(s) that guided their travels. They often added to, or corrected, these maps. Briar did not reference a base map. In early 1966, however, the most recent published map that included the Strickland River from about the latitude of the Elevala River in the south to the Blucher Range in the north was the ' 1957 Blucher Fourmil' published by the Department of Lands, Surveys and Mines, Port Moresby. In addition, the Ambunti sheet from the 1942 US Army series and a 1939 Island Exploration Company 'compilation' map covering the Western District north of the Elevala River may have been available. Figure 4 provides extracts from these three maps that show the Strickland River from about $15 \mathrm{~km}$ south of the Murray River to north of the border separating the territories of Papua and New Guinea. The 1942 map is seriously flawed in that it duplicates the Murray watershed, showing the junction of the Murray River (named) with the Strickland River near the Carrington junction to the south and, again (unnamed), at the annotation 'Whirlpool and Rapids' to the north. ${ }^{8}$

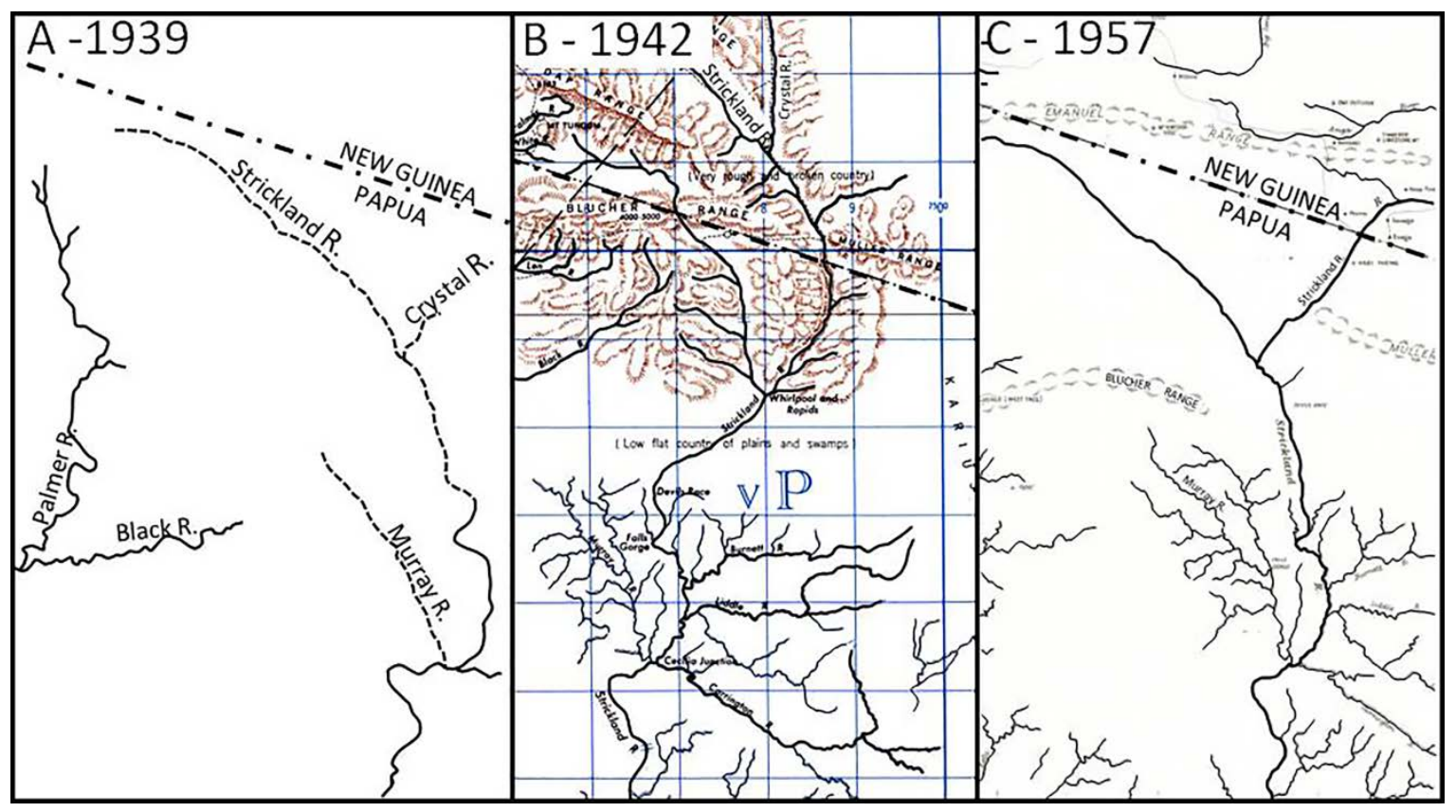

Figure 4. A: portion of a 1939 Island Exploration Company 'compilation map'; B: portion of the 1942 US Army Ambunti sheet; C: portion of the 1957 Blucher Four Mile sheet.

\footnotetext{
8 Peter D. Dwyer and Monica Minnegal, 'Captain Everill's Error: Mapping the Upper Strickland River in Papua and New Guinea, 1885-1979', Journal of Pacific History 53 (2018): 310-29.
} 
None of these maps suggests that an approach to the Murray River from the southwest would have entailed a substantial increase in altitude. Indeed, the flawed 1942 map references 'low flat country of plains and swamps' well to the northeast of the river named as Murray. Further, none of these three maps shows that a party approaching the Murray River from the southwest would have had to cross the headwaters of a reasonably substantial stream - the Dua - before reaching the watershed of the Murray. On these counts, therefore, Briar might be forgiven for misunderstanding his whereabouts. However, in 1947-8, Patrol Officer Des Clancy accompanied Australasian Petroleum Company geologists on a five-month survey of areas north of the Black River and southeast of the junction of the Strickland and Carrington rivers. The expedition departed from Kiunga and reached the Strickland after first following the Black River from west to east. Clancy's report, and accompanying map, reveal that on 25-6 December, after leaving Black River, he crossed two large streams draining to the south and on the 27th reached 'a large gravelly stream' that flowed southeast to join the Strickland River (Figure 5). ${ }^{9}$ The 'large streams' crossed on the 25th and 26th were headwaters of Dua River; the 'gravelly stream' of the 27th was Sigia. If Briar had had access to Clancy's report and map he would not have made the errors we have identified; he would have known that he could not have reached the Murray without crossing headwaters of the Dua.
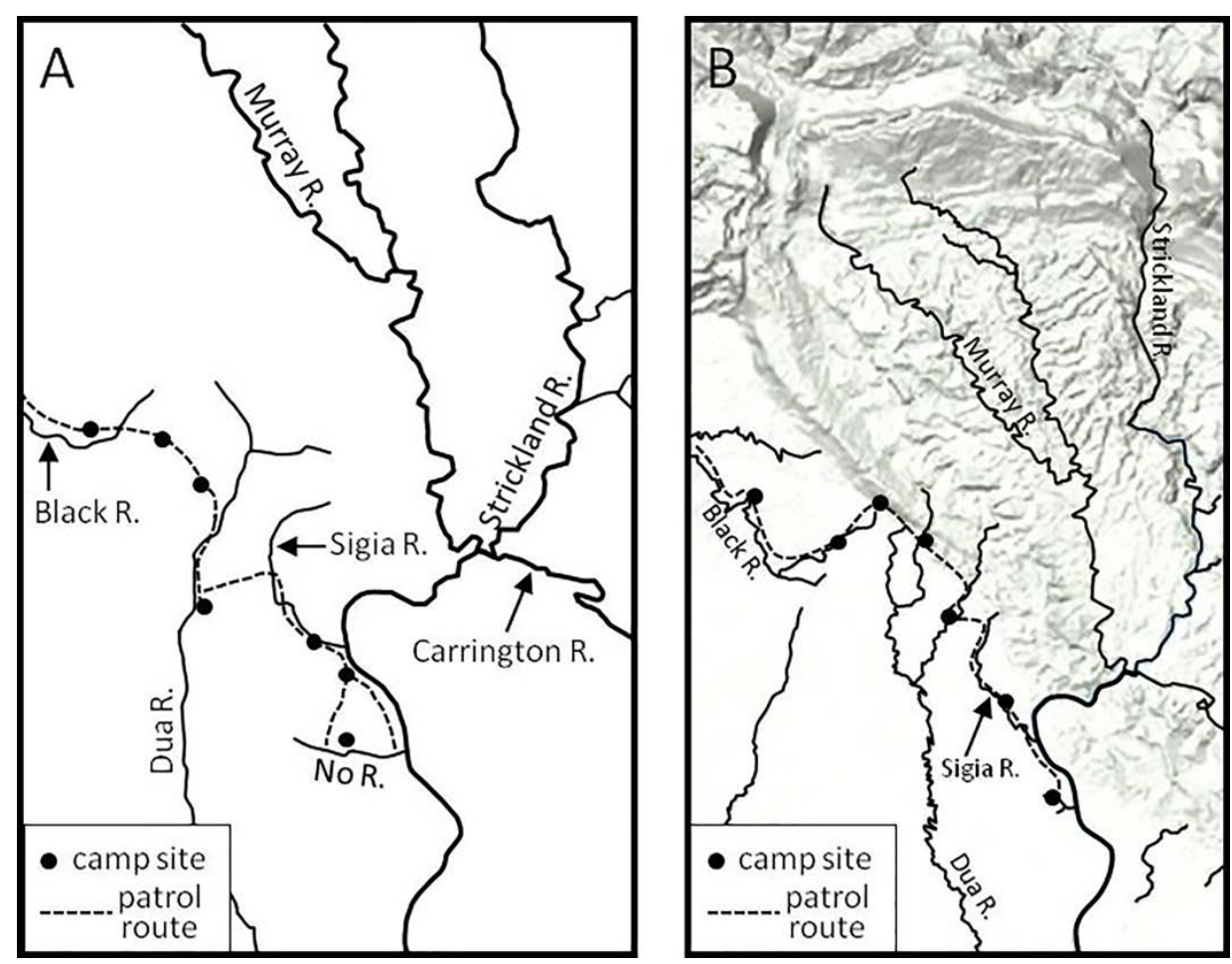

Figure 5. Des Clancy's route from Black River to Strickland River. A: redrawn from Clancy's 1948 map; B: reinterpreted by reference to satellite imagery.

We are now able to locate Briar on 25 January 1966 at a Konai community near the Dua River (Dunom to Briar). From here he travelled southeast to reach a stream which he named Crystal River and where he visited a community of 'Daba-speakers' [Kubo]. Briar's Crystal River is the stream that Clancy named 'Gravelly'. The local name for this stream is Sigia. The tributary Koto, which was recorded by Paterson, continues to mark a separation of Konai land to the northwest from Kubo land to the southeast. Briar moved between the two language groups. When he left 'Netemon' and headed north, Briar would have followed one

\footnotetext{
${ }^{9}$ Des J. Clancy, Daru Patrol no. 2 of 1947/48, 28 Nov. 1947-19 June 1948, National Archives and Public Records Services of Papua New Guinea, Patrol Reports, Western District, Daru Station, 1947-48, vol. 45, https://library.ucsd.edu/dc/object/bb2254555w.
} 
branch of Dua to its headwaters in the lower mountains, before turning northwest and, thereby, missing streams that drained east into the Murray River. When, finally, he turned south to follow 'a running cascade that drops in bulging steps' he was presumably descending the escarpment that, in 1969, McGregor named as 'Taktoki Ridge' rather than from higher reaches of the Blucher Range (Figure 3).

It is our judgement that Briar thought that his patrol route was as he depicted it on the map he produced. His errors arose, primarily, from incomplete knowledge about the terrain rugged mountains and deeply incised gorges as river courses - that he would have encountered had he been where he thought he was and, secondarily, from consistently overestimating distances travelled in the course of a day. However, it seems striking to us that men who, in later years, led patrols to the Murray-Strickland wedge made no reference to Briar's purported earlier visit in their own often quite lengthy reports. ${ }^{10}$ One thread that links all these reports is a concern, which matches our own in the present article, to locate in place the people known as Konai. Briar's report appeared to be an early and significant contribution to this question. The fact that it was ignored implies that later patrol officers had their own doubts about Briar's travels.

We have suggested that Briar genuinely thought he had travelled from south to north through the watershed of the Murray River. He was wrong but it is possible, we think, that he also 'wanted' this to be the case. On his map, north of the Murray, Briar shows a river flowing to the southeast to join the Strickland. He names this 'Worcester River', locating it between a 'Resignation Range' to the north and an unnamed range to the south. Briar did not visit this area. His depiction of 'Worcester River' matches depictions of the 'Strickland' in maps from 1939 and 1942 and of an unnamed river that joins the Strickland on the 1957 Blucher Four Mile map (Figure 4). This river, which seemingly drains southern slopes of the Victor Emmanuel Range, does not exist. Its representation on maps, initially as the Strickland, later as the Wungop, ${ }^{11}$ originates from errors by Charles Karius who thought he was following the Strickland River when he was actually following the Murray. ${ }^{12}$

\footnotetext{
${ }^{10}$ Robin I. Barclay, Nomad Patrol no. 3 of 1972/73, 6 Jul.-17 Sept. 1972, National Archives and Public Records Services of Papua New Guinea, Patrol Reports, Western District, Nomad Station,1972-73, vol. 10, https://library.ucsd.edu/dc/object/bb7817749q; Leo A. Bera, Olsobip Patrol no. 1 of 1972/73, 17 Aug.-18 Sept. 1972, National Archives and Public Records Services of Papua New Guinea, Patrol Reports, Western District, Olsobip Station, 1972-73, vol. 9, https://library.ucsd.edu/dc/object/bb59064698; C.R. Brillante, Olsobip Patrol no. 5 of 1971/72, 5-31 Jan. 1972, Olsobip Patrol Reports 1971-1972, National Archives and Public Records Services of Papua New Guinea, Patrol Reports, Western District, Olsobip Station, 1971-72, vol. 8, https://library.ucsd.edu/dc/object/bb6554940w; Rhys C. Carpenter, Olsobip Patrol no. 3 of 1971/72, 23 Aug.3 Oct. 1972, National Archives and Public Records Services of Papua New Guinea, Patrol Reports, Western District, Olsobip Station, 1971-72, vol. 8, https://library.ucsd.edu/dc/object/bb6554940w; W.A. Cawthorn, Nomad Patrol no. 13 of 69-70, 17 May-7 July 1969, National Archives and Public Records Services of Papua New Guinea, Patrol Reports, Western District, Nomad Station, 1969-70, vol. 7, https://library.ucsd.edu/dc/object/bb63160300; John K. McGregor, Olsobip Patrol no. 1 of 1968/69, 26 Jul.-31 Aug. 1968, National Archives and Public Records Services of Papua New Guinea, Patrol Reports, Western District, Lake Kopiago Station, 1968-69, vol. 5, https://library.ucsd.edu/dc/object/bb3756281s.

11 Peter D. Dwyer and Monica Minnegal, 'Charles Karius and Crystal Creek: Some Addenda to “Captain Everill's Error"', 29 June 2018, https://www.researchgate.net/publication/326059422 (accessed 1 October 2019).

1212 Barry Craig, 'How Karius Found a River to the North: The First 1927 Attempt to Cross New Guinea from the Fly to the Sepik' (Upper Sepik-Central New Guinea Project, 2013). www.uscngp.com/papers/ (accessed 31 May 2017); Charles Karius, 'Exploration in the Interior of Papua and North-East New Guinea: The Sources of the Fly, Palmer, Strickland, and Sepik Rivers', The Geographical Journal 74, no. 4 (1929): 305-20.
} 
Karius's account of his failed attempt to cross the island of New Guinea from south to north was both influential and controversial; influential in biasing map-making for decades and controversial because there was much uncertainty about the route he actually travelled. A problem that attracted particular attention was the location of a watercourse that was referenced as a 'creek' in Karius's diary and as a 'river' on his map.

Karius’s diary entry for 12 May 1928 states:

Moved off 6 a.m., travelling south-west and south. Came on a large stream of water coming from the north-east. Decided to follow this stream down to its junction with the Strickland. The water beautifully clear and cold. Have named this 'Crystal Creek'. After travelling for several hours noticed that the class of stone in the river bed was gradually changing. Flashes of snow white showing up with the red and brown of the original formation. Once again entering the limestone belt. Came to the junction of the Strickland and Crystal $4.15 \mathrm{pm}$. Nothing but limestone here. Made camp. (Karius 1928)

Opinions about the location of Crystal Creek/River, and whether it was a tributary of the Strickland or the Murray, are extremely variable (see Figures 4A and 4B). ${ }^{13}$ The suggestions of Campbell, Black, Rand and Brass, and Ticehurst fail to direct attention to a stream in which the water would be 'beautifully clear and cold'. We think it was this description, however, that caught Briar's attention. Comparison with other patrol reports indicates that the stream Briar named as Crystal is Sigia and, relative to all nearby streams, it could well merit this name. ${ }^{14}$ The primary catchment of Sigia is foothills and lower mountains to the north rather than swamps to the west. It has a wide bed of waterworn pebbles that include chert, limestone and ammonite-bearing nodules. It is not completely overhung by rainforest vegetation, as are smaller streams such as Moiyo (Figure 2) to the east. When not in flood, the water runs clear and the bed is well suited to walking.

On his map, Briar showed 'Crystal River' flowing from the northeast (Figure 1) and joining the Murray. However, Briar had followed this river - that is, Sigia - for only a short distance. Had he travelled further he would have appreciated that it joined the Strickland, not the Murray, that he was therefore much further south than he believed, and that this could not be the river that Karius had named 'Crystal'. Briar's depiction was presumptive. It seems that

\footnotetext{
${ }^{13}$ Stuart Campbell, 'The Country between the Headwaters of the Fly and Sepik Rivers in New Guinea', The Geographical Journal 92 (1938): 232-55; James L. Taylor, Mount Hagen Patrol no. 1 of 1938/39, p. 246, National Archives and Public Records Services of Papua New Guinea, Patrol Reports, Western Highlands District, Mount Hagen Station, 1938-39, vol. 1, https://library.ucsd.edu/dc/object/bb7988228d); Craig, 'How Karius Found a River to the North', 15-19; Dwyer and Minnegal, 'Charles Karius and Crystal Creek'; Austin L. Rand and Leonard J. Brass, 'Summary of the 1936-1937 New Guinea Expedition. Results of the Archbold Expeditions. No. 29', Bulletin of the American Museum of Natural History LXXVII, Art. VII (1940): 341-80; Noel Ticehurst, 'Papua New Guinea Explorations. North West Patrol 1926-1928: The North-West Patrol Remapped Part 2', Royal Australian Survey Corps Association (NSW) Newsletter, June 2012, 5-14.

14 Other geographic names that originate from Briar are Mandarin River, Red River, Ruth River, Worcester River, Rhodesia Swamp and Resignation Range (Fig. 1). We are unable to suggest motivations for these names and have not encountered them in earlier or later patrol reports. We note, however, that a Jack Worcester served as a patrol officer throughout the 1950s and subsequently, to at least early 1970, held senior administrative positions in Papua and New Guinea. Minister for External Territories, Hon. C. E. Barnes MP, 'Papuan and New Guinean Local Government Councillors to Visit Australia', 19 Feb. 1970, https://parlinfo.aph.gov.au/parllnfo/search/display/display.w3p;query=Id\%3A\%22media\%2Fpressrel\%2FHPR1 0020349\%22;src1=sm1 (accessed 1 October 2019).
} 
when he prepared a map showing his patrol route he was, at the same time, attempting an unstated contribution to the puzzles of geography that Karius had initiated 38 years earlier. There was, however, no follow up, and ultimately no explanation, because after this patrol Briar resigned from the Department of District Administration. It is ironic that Briar's own mapping errors may have resulted from his efforts to correct earlier errors by someone else.

The patrol officers whose travels and encounters are recorded in the reports now available through the University of California library were charged with rendering the places they traversed and the people they met legible to, and governable by, the colonial state. They took this commission seriously. Their concern to generate accurate renderings of places and people is well attested by their ongoing efforts to both add to and correct the reports of those who went before them. Sometimes misjudgements were made in seeking to refine previous work. Sometimes assessment of contributions was expressed by silence. Such glitches in what was always an extremely complex process do not deny the commitment of the young men who served as kiaps in Papua and New Guinea. No report can stand alone, or be read alone, as a guide to the people and places encountered. 